\title{
Revitalization of islamic education at the imam hatip school in turkey
}

\section{Bibi Suprianto}

State Islamic Institute (IAIN) of Pontianak

bibisuprianto78@gmail.com

DOI: $10.18326 /$ attarbiyah.v5i1.43-59

Submitted:

29 July, 2020
Accepted:

14 September, 2020
Published:

17 September, 2020

\begin{abstract}
This research tells about the revitalization of Islamic education at the Imam Hatip school during Erdogan's leadership. Also, this study reveals the beginning of Islamic education in Turkey during the Ottoman Empire, the Attaturk government, and continued by Erdogan's leadership. This research aims to find out about Islamic education during Erdogan's reign, such as the Imam Hatip Islamic schools, which are the focus of modern Islamic education by the Turkish community. Besides, the research objective is to prove Islamic schools in Turkey developed the contemporary curriculum. The method used is library research, which focuses on journals and books as primary data. The results and implications of the study are in the form of texts that provide strong research arguments about modern Islamic education that is currently developing in the world.
\end{abstract}

Keywords: revitalization, imam hatip, modern. 


\section{INTRODUCTION}

Turkey is an Eastern European country that has different backgrounds and religions compares to other European countries. Turkey is ranging from the Anatolian peninsula in Asia to the Balkans in Southeast Europe. Turkey also limits the black sea in the north, Greece in the west, Iran in the east, and the Mediterranean Sea in the south.

Turkey is famous for its Constantinople as the capital of Byzantium, which now changed its name to Istanbul. Istanbul is a city that connects Asia and Europe with a blend of Middle Eastern and Western European art. Constantinople, usually called as Aya Sofia (Hagia Sophia), was originally a church and then turned into a place of worship for Muslims. In the government of Kemal Attaturk, it becomes a museum. When the Erdogan government was re-inaugurated in early July 2020, it is turned again as a mosque.

Negotiating the problem of religion is a multifaceted process, where religiosity is only one of many factors (Chaniotis, 2003). Back to the history of Islamic education in Turkey when Sultan Hamid II led it with Islamic teaching in Usmaniyah. Many institutions teach studies of Islamic law (sharia), while the khalaqa system teaches many ways to draw closer to Allah by exemplifying the life of a Sufi (Badwi, 2018). These educational institutions teach the science of Sufism, the Qur'an, and theology of Islam, which also became a curriculum in the Ottoman government. In the city of Istanbul, there have been no less than 355 public primary schools and seven private primary schools. In Aydin, there are no less than 1,379 schools, consisting of 669 schools for boys, 92 primary schools specifically for girls, and 669 other schools mixed between men and women. In Kastamonu, which is also the Ottoman territory, there are 855 primary schools. In addition to that, in Bursa, there are also 56 public schools and 1,406 private schools (Makarom, 2015).

The history of modern Turkey starting with the collapse of the empire of the Islamic Ottoman led by Mehmed VI. Then, it is replaced with the establishment of the Turkish republic, which was led firstly by Kemal Attaturk as president. The governmental system brought by Kemal Attaturk is a system of governmental secularism in terms of the education and lifestyle of the Turkish people. He aims to get Turkey to developed countries through its conception, which is based on a (Western) European paradigm (Kholis, 2018). As John Darwin said, that we live in a world made of royal states and 
between ethnic and national identities, which are often forged in collaboration with these empires as opposed to them (Mulaj, 2016). The West people rose; one by one, the Ottoman Empire became part of its power (Halim, 2016).

The secular education sector brought by Kemal Attaturk was changed to modern secular Islamic education under Erdogan's leadership. Islamic schools in many areas such as Istanbul and Ankara, as well as Islamic universities, form a generation of pious. Islamic education certainly has a significant impact on the lives of students and makes them very useful individuals (Mahesar, 2018).

During Erdogan's reign, Islamic education first experienced a decline due to changes in the secular curriculum stem, which was changed to a modern secular Islamic education system. Teachers who used to be teaching the secular education system were stopped for no particular reason. Education began to decline and became a polemic for Turkish society. Not long later and slowly rise back Islamic education and make education was seen as an Islamic education of future changes.

In the era of 70s Islamic education, such as Imam Hatip, became a modern-based education. An education system that contains a general curriculum based on science and Islam has colored Turkey. Imam Hatip is a modern Islamic educational institution because this education has been reincarnated from secular education before the Erdogan government, both its management and learning process and subject matter that is not only religious but also other general sciences. That is due to the emergence of Islamic education, such as Imam Hatip, which is based on modern secular Islam because of an educational curriculum that is in contact with European teachings by promoting Islamic education and general education. Medium Islamic education in Turkey is a modern phenomenon growing and developing as part of the process of renewal of Islamic teaching.

This paper discusses the revitalization of Islamic education under Erdogan's government as seen from the history of Turkish Islamic education in the past where Islamic education experienced a decline in the middle of the century, then the growth of Islamic education in Turkey which changed the system of educational secularism into modern secular Islamic education during the government Erdogan. 
Modernization and education that is developing rapidly in the present age to provide competition in education. Islamic education that has undergone moderation in an educational challenge in the form of science and technology, Islamic teachings, secularism, and how to revitalize the model of Islamic education in the Modern Period has taken place.

\section{METHOD}

This research is sourced from the results of data using qualitative research. A qualitative approach is a way of working that emphasizes the aspects of data deepening to get the quality of the results of a study (Ibrahim, 2015). At the same time, the method used in this study is in the form of library research. It is because the data or materials needed to complete the analysis come from the library in the form of books, encyclopedias, dictionaries, journals, documents, magazines, and so on (Harahap, 2014).

\section{RESULTS AND DISCUSSION}

Islamic education institutions is a forum for the formation of healthy and insightful Muslim characters in the social world. Religious education must carry out a philosophicalparadigmatic reorientation of how to build Islamic educational institutions as a forum for the formation of a strong Muslim character and broad-minded in the social world. Religious education must reorient philosophical-paradigmatic of how to build an understanding of the diversity of learners more inclusive-pluralist, multicultural, humanitarian, dialogue-persuasive, contextual, substantive, and socially active (Muliadi, 2012).

Imam Hatip School, located in Turkey, is one of the schools that have modern educational competitiveness with an increasing number of educators in 2018. The number of which is known as follows: 


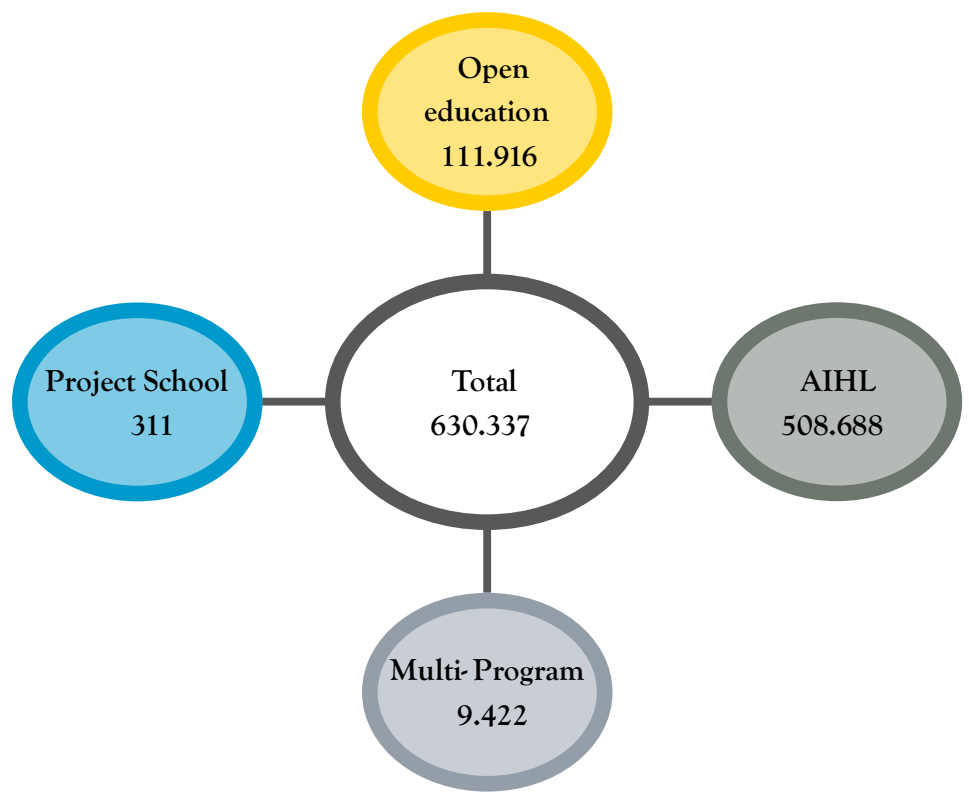

Figure 1. Data on the number of Imam Hatip Higher Education Schools 2018.

Sources: (Tanrikulu \& Ucar, 2019)

There was an increase of Islamic education at the Imam Hatip school in 2018 with a total of 630,337, such as open education 111,916, Anatolian Imam Hatip Lisesi (AIHL) by 508,688, Multi-program 9,422, and project school 311. This makes evident that the Erdogan government has targeted the readiness of the Turkish generation to face progress education and to print great eras.

\section{Modernization and Islamic Education}

Islamic education always undergoes a change of times, which changes illustrate the progress of Islamic modernization. Changes that occur simultaneously with modernization (Rosana, 2011). The role of knowledge and technology is needed in the process of modernization (Matondang, 2019). This modernization is what makes a change in every technology-based education.

Technology-based Islamic education is a prerequisite for progress in opening the horizons to the rise of Islam throughout the world. It has been explained how the influence of globalization is very fast, fundamental by ruffling the pattern of the old order and encourage the emergence of a new order due to advances in information and communication technology (Kurniawan, 2018). The nature of conservative Islamic 
education towards the fundamental values of Islamic teachings makes Islamic education different from other education and still exists amid globalization (Ulum, 2012). Such education develops among the people and becomes a path of progress for the country.

Imam Hatip Islamic education school is one of the modern Islamic education, which has $60 \%$ secular education and $40 \%$ religious education. In these schools, religious courses including Qur'an, Arabic, Tafsir (exegesis of the Qur'an), Hadith (traditions of the Prophet), Qaalam (Islamic Theology), Fikh (Islamic Jurisprudence), and Sirah Nabawiyah (Prophet biography). Comparative religious rhetoric and history, secular courses consisting of social studies and science, including literature, history, geography, foreign languages, philosophy, health, science, music, visual arts, mathematics, physics, chemistry, and biology (Aslamaci \& Kaymakcan, 2016).

This education has become Turkey's progress to form a religious and broadminded generation to find out life in the world from the historical facts of the rise of Islam and the improvement of modernization now. The fact that the president of the Turkish Republic and many prominent figures of the AKP as the ruling party, was graduated from Imam Hatip's school is very important because it reinforces the perception that they are good Muslims and highlights the school as a successful model in Islamic education (Junaedi, 2016). Imam Hatip School is a history for Muslims in Turkey as the development of Islamic teaching.

\section{The Challenges of Islamic Education to Imam Hatip in Modern Times}

The challenge of Islamic education in modern times is that of extensive Islamic knowledge and information technology that must use today. A society that develops forward in the understanding of society with the main characteristic of a free competition based on that success is primarily determined by one's education, people who continue to seek knowledge to size and master science and technology by relying on reason and mind. So the challenge of Islamic education must understand all forms of science and technology in education that can provide a change for the nation. Thus, Islamic education must not only focus on scientific issues and teaching but also must take a position as an agent of a peaceful Islamic identity (Zahran, 2019).

Islamic education, in general, is the personality of a person who makes insan kamil with the pattern of taqwa insan kamil, which means a person who is perfect spiritually and physically because of devotion to Allah SWT (Ainiyah \& Karsiyah, 2017). 
Islamic Education in Imam Hatip combines science and Islamic cultures.

Education plays an important role in social, cultural, economic, and ideological processes, independent reproduction of how reproduction is actualized, a significant increase in the number of Imam Hatip and developments in their quality suggests that mainstream education will be carried out at Imam Hatip School where subjects are related to the beliefs, worship, and moral principles of the Islamic sect are taught and increase the concern that society will be converted to Islam (Bayruk, 2020).

Imam Hatip's education became a very influential Islamic education for the Turkish state. So, if the character of the nation, one of which is young people, is taught history, which leads personal awareness, perspectives, and mental life through existing media such as socio-cultural institutions, eating character will form Islamic religious insight (Pasiska, 2019). These challenges make an educational opportunity to grow the nature of a nation.

\section{Knowledge Science Teknologi vs. Faith and Taqwa}

Science and technology is the knowledge that teaches sophistication in a humanmade system. The findings of science and technology have spread results that bring progress, and the impact is felt for the lives of all humanity (Aripin, 2018). The experiences of the Ottoman Turks, then the Republic of Turkey, is also typical of the knowledge of the Islamic world in general, in terms of the adoption of the West Science and Technology only on practical and pragmatic considerations (Munir, 2017). Faith and Taqwa are the foundation for Muslims to make Islamic education insightful and understand technological advancements. Now it is only for Islamic education itself to empower itself to truly be an alternative education that has a competitive advantage in the face of globalization (Azra, 2003). The role of Islamic education as the character of a nation. It means being polite and strengthening one's identity in the midst of the globalization era (Aiyub \& Huwaida, 2015).

Imam Hatip School is a school that Erdogan founded to be able to become a religious generation in the future. Imam Hatip School, in the eyes of the society, is not just a vocational school. At the same time, it is where children learn about both their religion and the world. Besides, these schools become essential tools where society risk their claims on education and the state (Batar, 2017). This means that science and technology have been owned by the Imam Hatip school, which has taught the importance of Islam and the 
progress of the country. That progress becomes a fortress for the formation of pious and competitive generations for the future so that many other countries who want to attend modern Islamic education are famously brought by Imam Hatip's school.

\section{Islamic vs Secularism}

It cannot be denied if secularism and Islamic education are related to one country. Secularism is an understanding that separates world life from the hereafter in all aspects of life, both in terms of religion, economy, education, politics, social, and so forth (Jamaluddin, 2013). It was proven when the Turkish state first became a Turkish republic and was led by Kemal Attaturk is president in Turkey, a culture of secularism that entered into government regulations. During the republic, most people were alienated from the state because the policy of radical secularism was unacceptable to the majority, which never stopped them from trying to become equal members of society and participants in leadership (Gelovani, 2011). Secularism, as a form of secularization, is a process of rejection or denial of religious norms from and in life in the world (Pachoer, 2016). When the Attaturk leadership of Islamic religious norms mixed with European secular thought.

In contrast to Turkish education under Erdogan's current leadership, Imam Hatip's school, they are more tolerant of secular culture, which is slowly being transformed into modern secularism. The Turkish education system, which has long provided secular students, has been scrutinized by the government after the coup attempt on July 15, 2006, that culminated in the dismissal of more than 33,000 teachers and the closure of a numbers of schools, at the same time, the parta of justice and development inspired by Islam. The ruling has significantly increased the number of religious schools, known as Imam Hatip, and promoted Erdogan's recognized goal of raising a generation by Turkey (Dan, 2020). The gradual abolition of the curriculum by establishing Islamic schools such as Imam Hatip made changes to education to foster a godly, wise and robust character in Turkey (Anita \& Badrun, 2019). With the majority of its Muslim community, Turkey is seen as another or outsider to other EU members: supporting Turkey to join, together with requiring a rethinking of the idea of European secularism (Notianti, 2018). Of course, with the leadership brought by Erdogan, Turkey has become a country that has a role to play in overcoming the problem of secularism. 


\section{Spiritual vs. Material}

Cultivation of spiritual values in Islamic education is needed for the nation. School personnel job satisfaction based on spirituality values will have an impact on personnel performance, such as productivity, decreased absenteeism, reduced levels of error and undisciplined, and increased efficiency (Anam, 2016). The spirit of modern Turkish society to become a modern and democratic country is always accompanied by a deep awareness of the character and ideals for Turkey and Islamization (Za, 2016). The spirit that makes Turkey able to provide substantial Muslim opportunities to compete in the modern world.

Imam Hatip School has an equal vision and mission to improve spirituality in educational materials. Teaching is placed on the process of learning a concept or event in the environment, in which case it is necessary to select the essential images based on specific criteria on certain subjects that are mapped holistically, logically, and psychologically (Gafar, 2006). The Imam Hatip school diversity program will be maintained and will be aligned with a flexible and modular structure from general secondary education. Vocational development programs will be organized to improve vocational qualifications of foreign language teachers, Arabic course books will be designed in a holistic manner, aimed at strengthening all language skills, including listening, speaking, reading, and writing skills (Republic of Turkey Ministry of National Education, 2019). With this material, the program can help support student learning and make quality Islamic education.

\section{Revitalization of Islamic Education Models in Modern Times}

Improving the quality of Islamic education is one form of the revitalization of an education. While the critical issue of the revival of madrasa education (religious schools), namely in the curriculum, it is necessary to unite religion and general science (Aripin, 2018). Islamic education in the future must prioritize applied science, which is very applicable, not only in religious sciences but also in the field of technology (Khairuddin, 2018). So that curriculum and education services become a factor for the development of Islamic education.

There is a one-year application preparation class in several schools ensuring that each student learns at least one foreign language, ideally beside his native language, during 
school life at Imam Hatip High School (Tanrikulu \& Ucar, 2019). So that in preparation for a generation of high-quality language becomes one of the waves to be able to compete in the future of a country. The revitalization of Islamic education at Imam Hatip School illustrates Erdogan's struggle in reviving Islamic moderation today. Even Islamic education at Imam Hatip's school can present a reward figure for Muslims.

The concept of education curriculum education becomes a development for advancement in well-designed knowledge. The curriculum concept develops in line with the development of educational theory and practice, as well as variations following the flow or approach of education adopted (Sukmadinata, 2015). Considering this situation, developing the Turkish curriculum has examined a reform philosophy that supports children's active construction of their knowledge through problem-solving, communication, exploration, reflection, and other inspirational processes involving highlevel cognitive abilities. (Stein, Grover \& Henningsen in Orakci, Durhali, \& Ozkan, 2018). Another vital feature of curriculum change is that the content or what is taught does not change markedly, but only slightly revised; therefore both the old curriculum and the new curriculum look very similar (Orakci, Durhali, \& Ozkan, 2018). This curriculum can foster academic achievement that supports economic, political, institutional, and educational.

Besides that, what is fundamental for a revitalized Islamic education is the development of science, which is an evaluation of knowledge to find out to what extent the educational process has improved. This has become a revitalization of Islamic education that occurred at the Imam Hatip school. They believe that Imam Hatip's students have the potential, ability, and strength to develop.

The vision of the mission of Islamic education at Imam Hatip's school uses a slogan, goals, and targets for the development of Islamic teaching. The motto that makes education have a Pull style for the community to be able to send their children to Imam Hatip's school, the goal is a reason to be able to compete in the world of work and create a generation of pious and dignified. 


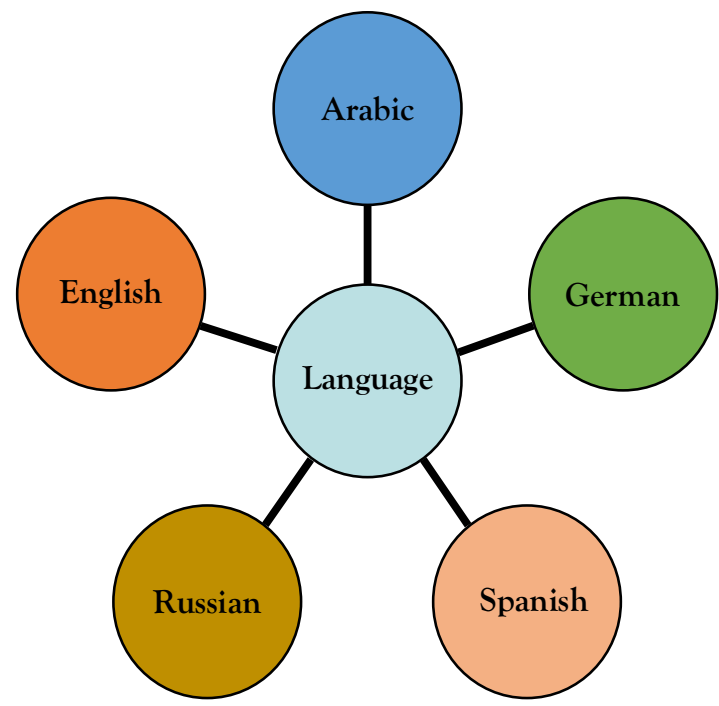

Figure 2. Imam Hatip High School prepares language classes. Sources: (Tanrikulu \& Ucar, 2019)

Language education in a country is one of the breakthroughs in a state to be able to grow the character of students who can open up insights to understand development in another country. The causes of language development disorders are numerous and widespread, all disorders ranging from the process of hearing, the transmission of impulses to the brain, brain, muscles, or sound-making organs (Marisa, 2015). So that the development and adequate language training can provide quality in Islamic education.

The diagram explains that Turkish education in the future has a vision to encourage education in the international community. One of the educational institutions, the Imam Hatip school, is the spearhead of Turkey's success in achieving future progress.

\section{Character Education in the Era of Globalization}

The progress of Islamic education is increasingly developing. Islamic education teaches knowledge related to one's Muslim behavior (Suprianto, 2019). This development is marked by a character that is in an educator. Character education is the overall dynamics of interpersonal relationships with a variety of dimensions, both from within and from outside him, so that the person lives up to habits so that he can be more responsible for his own growth as a person and the development of others in their lives (Koesoema, 2007). 
The globalization era has brought many social changes, covering various aspects, one of which is moral and behavioral change (Hamdi, 2019). The behavior is what describes a character. Character education is also contained in the Koran where when Allah explains Surah Luqman about the importance of a father to pay attention to the education of a child, how to educate children in Islam, and the command to obey both parents as long as the content is not immoral to Allah (See Q.S Luqman, 12-13).

Globalization in character has a problem with people who take education. For this reason, the character of a believer must be educated with religion, not with pure knowledge (Baihaqi, 2019), because the character of a believer is essential in the era of globalization. The current conditions and situation seem to demand character education that needs to be transformed early, namely from early childhood education, primary education, secondary education, and higher education holistically and continuously (Budiwibowo, 2013). The challenges of knowledge in the Globalization era provide anxiety for the community because, in the Globalization era, educators must be able to understand the technology and even have digital media to develop modern education.

This can be seen when the emergence of online education conducted by the government was caused by a significant event that hit the world, namely Covid 19. All faceto-face based education is now rapidly changing, utilizing online education. A systems approach is indispensable in the explanation of education, because in the current global era, the world of education has developed in such a way that it becomes an issue (Lestari, 2018). This has become an educational challenge in the $21^{\text {st }}$ century.

Globalization demands a change of time that wants to pay attention to educational institutions to continue to develop. Even the portrait of education today makes people wonder about a change. The use of various technologies is indeed very easy for life, but even the digital lifestyle will increasingly depend on the use of cellphones and computers (Setiawan, 2017). In other words, the problem of education in the era of globalization depends on technological progress that develops in a place or country.

Turkey Islamic education is a challenge for educators in overcoming the education system and the Globalization era. The charters they have can contribute to knowledge that is beneficial to the country. New policies reform the importance of English as Turkey competes in the process of globalization and becomes a member of the EU, such as Turkey's national policy at the macro level has been established to serve 
and socio-economic purposes, and the role of English as the most prominent foreign language in the school curriculum thus serves as a tool mediation for Turkey to achieve the goals of globalization (Kirkgoz, 2008). The most essential thing in the era of globalization is the development of increasingly global English so that the realization of character education with the spirit of leadership and responsibility is a manifestation of the presence of Imam Hatip School educators. Schools that provide opportunities for students to develop their abilities both from science, research and Islamic education which become a guide for character formation in the era of Globalization.

\section{CONCLUSION}

The revitalization of Turkish Islamic education under Erdogan's leadership is a new breakthrough to realize a genius and religious generation. Growing a strong character is one of Erdogan's goals to create a golden generation that can make a big difference. Education supported Turkey's revival from a story of struggle during the Ottoman empire until the Turkish republic government was present as a revitalization of education.

The Imam Hatip School, which provides Islamic education in general scientific insights such as studying technology (IT), five languages besides the mother tongue in Turkey, and even modern curriculum, has become a top concern for people who are interested in Islamic education.

The revitalization of Islamic education in Turkey was formed when Erdogan transformed public education into Islamic education. This is the immense belief for the Asian-Europe country, which was once a state of civilization in the most remarkable Islamic history in Turkey.

The teachings of Islam and secularism in modern-day Turkey make Islamic education have a new challenge in the form of a modern secular Islamic education curriculum. Those who understood Kemal Attaturk's leadership first brought the tradition.

Science and technology in Islamic education at Imam Hatip's school teaches about the world and the hereafter and their country to understand all forms of scientific change in the country. At the same time, faith and piety are teaching about their closeness to the Khaliq through the education of the Qur'an, Arabic, Sufism, and other Islamic education. 
Spiritual in Islamic education became a challenge to the interest of Turkish society when Imam Hatip's education was established, namely their interest in making Islam with high insight. So that Islamic education materials are mixed with the world of technology that can make a breakthrough in the thinking of a broad Islamic education in the world. Turkey's progress was led by Erdogan to make Islamic education a place to shape youth leadership that was ready for a career and compete with globalization that approached a country.

The golden generation that is said to be present in every country has slowly been formed in the Imam Hatip school. This school will provide an Islamic journey to modern Islamic educational institutions that might be applied to every country. Imam Hatip School has become the center of attention for the people of the world. Such attention can be seen when the education system is increasingly improved in terms of language.

English is a compulsory curriculum for Turkish students to be a generation that can contribute to Europe. These contributions can be seen from the curriculum made by Turkish educational institutions.

\section{REFERENCES}

Ainiyah, Q., \& Karsiyah. (2017). Konsep Kesatuan Iman, Iptek dan Amal MenujuTerbentuknya Insan Kamil dalam Perspektif Pendidikan Islam. Jurnal Istawa: Pendidikan Islam, 2(2), 77-114. DOI: 10.24269/ijpi.v2i2.620.

Aiyub \& Huwaida. (2015). Anak-Anak Muslim dan Dampak Era Globalisasi Bagi Pendidikan Islam Mereka. International Journal of Child and Gender Studies, 1(2), 1 14.

Anam, K. (2016). Pengembangan Menejemen Spiritual di Sekolah. Jurnal Ta'allum, 4(1), 101-121. DOI: 10.21274/taalum.2016.4.01.101-121.

Anita \& Badrun. (2019). Karakter Religious pada Mahasiswa Program Pascasarjana Universitas Negeri Yogyakarta. Jurnal Pendidikan Karakter, 9(2), 163-178. DOI: $10.21831 /$ jpk.v9i2.26838.

Aripin, S. (2018). Revitalisasi Pendidikan Islam pada Madrasah. Jurnal Kordinat, 17(1), 167-186.

Aslamaci. I., \& Kaymakcan, R. (2016). A Model for Islamic Education from Turkey: The Imam Hatip School. British Journal of Religious Education, 1-14. http://dx.doi.org /10.1080/01416200.2015.1128390.

Azra, A. (2003). Pendidikan Islam Indonesia dan Tantangan Globalisasi. JPI FIAI Jurusan Tarbiyah, 9(6), 19-30. DOI: 10.32729/edukasi.v6i4.269. 
Badwi, A. (2018). Sejarah Pendidikan Islam di Kerajaan Turki Usmani. Jurnal Pendidikan dan Studi Islam dari Ash-Shahabah, 4(1), 92-97.

Baihaqi. (2019). Intergrasi Ilmu Ushul, Fiqih dan Tasawwuf dalam Membangun Karakter Mukmin pada Peserta Didik. Journal of Research and Thought of Islamic Education, 2(1), 90-106.

Batar, Y. (2017). Imam Hatip Schools' Mission Against "Religious" Manipulations. Talim: Journal of Education in Muslim Societies and Communities, 1(1). 45-49. http://dx.doi. org/10.12738/talim.2017.1.0005.

Bayruk, H. (2020). The Role of Religious Education and Hegemony Construction: The Case of Imam Hatip School in Turkey. International Journal of The History of Education, 1-18. https://doi.org/10.1080/00309230.2020.1762677.

Budiwibowo, S. (2013). Membangun Pendidikan Karakter Generasi Muda Melalui Budaya Kearifan Lokal di Era Global. Jurnal Pendidikan Dasar dan Pembelajaran, 3(1), 39-49. DOI: 10.25273/pe.v3i01.57.

Chaniotis, A. (2003). Negotiating Religion in the Cities of the Eastern Roman Empire. Open Edition Journal of Kernos, 16(2), 177-190. DOI: 10.4000/kernos.821.

Dan, B. In Turkey's New Curriculum, Ataturk, Darwin and Jihad Get Face-Lifts. The New Work Times. Https://www.nytimes.com. Accesed 9 February 2020 (11:54).

Gafar, I. A. (2006). Kurikulum dan Materi Pendidikan Agama Islam. Jurnal Hunafa, 3(1), $37-52$.

Gelovani, N. (2011). Islam and Religious Education in Turkey. Ibsu Scientific Journal, 5(2). $35-50$.

Halim, H. (2016). Pendidikan Islam pada Masa Daulah Usmani. Jurnal Al-Ishlah, 14(2), $126-136$.

Hamdi, S. (2019). Menghadirkan OASE Spiritual di Tengah Tantangan Global: Studi Pondok Dzikir Miftahus Sudur Palangka Raya. Proceeding of the $4^{\text {th }}$ Borneo Undergraduate Academic Forum, 505-512.

Harahap, N. (2014). Penelitian Kepustakaan. Jurnal Iqra', 8(1), 68-73.

Ibrahim. (2015). Metode Penelitian Kualitatif. Bandung: Alfabeta.

Jamaluddin. (2013). Sekularisme: Ajaran dan Pengaruhnya dalam Dunia Pendidikan. Jurnal Mudarrisuna, 3(2), 309-327.

Junaedi, M. (2016). Imam Hatip School (Imam Hatip Lisesi): Islamic School in Contemporary Secular Turkey. Journal of Social Science and Religion, 1(1), 121-138. DOI: 10.18784/analisa.v1i1.219.

Khairuddin, M. (2018). Pendidikan Islam Tradisional dan Modern. Jurnal Tasyri, 25(2), 92-105.

Kholis, N. (2018). Islamic Education by Badiuzzaman Said Nursi in Secularic Period of Turkey. Attarbiyah: Journal of Islamic Culture and Education, 3(2), 153-173. DOI: 10.18326/attarbiyah.v3i2.153-173. 
Kirkgoz, Y. (2008). Globalization and English Language Policy in Turkey. Journal of Educational Policy, 20(9), 1-22. DOI: 10.1177/0895904808316319.

Koesoema, D. (2007). Pendidikan Karakter. Jakarta: PT Grasindo.

Kurniawan, S. (2018). Globalisasi, Pendidikan Karakter dan Kearifan Lokal yang Hybrid Islam pada Orang Melayu Kalimantan Barat. Jurnal Penelitian, 12(2), 317-354. DOI: $10.21043 /$ jp.v12i2.4899.

Lestari, S. (2018). Peran Teknologi dalam Pendidikan di Era Globalisasi. Jurnal Edureligia, 2(2), 94-100. DOI: 10.33650/edureligia.v2i2.459.

Mahesar, R.A. (2018). The Role of Islamic Education in Social Change: A Case Study of The Elementary Schools of District Shaheed Benazir Bhuttu Abad, Sindh. JournalJRS, 2(1), 31-44. https://www.researchgate.net/publication/329505412

Marisa, R. (2015). Permasalahan Perkembangan Bahasa dan Komunikasi Anak. Jurnal Pendidikan Sekolah Dasar (JPsD), 1(2).

Makarom. (2015). Pendidikan Islam pada Masa Kerajaan Turki Usmani 1300-1922 M. Jurnal Tarbiyah, 1(1), 109-126.

Matondang, A. (2019). Dampak Modernisasi Terhadap Kehidupan Sosial Masyarakat. Jurnal Wahana Inovasi, 8(2), 188-194.

Ministry of Education Turkey. (2019). Turkey's Education Vision 2023. PP. 139.

Mulaj, K. (2016). War and State Making at The End of Empire: Ottoman Collapse and The Formation of The Balkan States. Journal Peace E Change, 41(4), 539-565. DOI: $10.1111 /$ pech.12205

Muliadi, E. (2012). Urgensi Pembelajaran Pendidikan Agama Islam Berbasis Multikultural di Sekolah. Jurnal Pendidikan Islam, 1(1), 55-68. DOI: 10.14421/jpi.2011.11.55-68.

Munir, M. (2017). Modernisasi Pendidikan Islam dalam Perspektif Nurcholish Madjid. Jurnal Evaluasi, 1(2), 202-222. DOI: 10.32478/evaluasi.v1i2.73.

Notianti, F. A. (2018). Pengaruh Agama Islam dan Identitas Turki dalam menghambat Perluasan UNI Eropa. Jurnal Analisis Hubungan Internasional, 7(3), 95-105.

Orakci, S., Durhali, M., \& Ozkan, O. (2018). Curriculum Reforms in Turkey, Journal Economic and Geopolitical Perspectives of the Commonwealth of Independent State and Eurasia-ER, 10.4018/978-1-5225-3264-4.ch010, 225-251.

Pachoer, R. D. A. (2016). Sekularisasi dan Sekularisme Agama. Jurnal Agama dan Lintas Budaya, 1(1), 91-102.

Pasiska. (2019). Pendidikan Nilai-Nilai Islam di Era Globalisasi. Journal of Research and Thought of Islamic Education, 2(1), 107-125.

Rosana, E. (2011). Moderisasi dan Perubahan Sosial. Jurnal TAPIs, 12(2), 31-47.

Setiawan, W. (2017). Era Digital dan Tantangan. Seminar Nasional, ISBN.978-602-50088$0-1$. 
Sukmadinata, N. S. (2015). Pengembangan Kurikulum. Bandung: Rosdakarya.

Suprianto, B. (2019). Pengembangan Media Digitalisasi pada Sekolah Dasar Swasta (SDS) Islamiyah Pontianak dalam Menyongsong Pendidikan Islam 4.0. Prosiding Konferensi Integrasi Interkoneksi Islam dan Sains, 2(1), 271-274.

Tanrikulu, F., EO Ucar, M. A. (2019). Religious Teaching in Turkish Educational System Imam Hatip School. Istanbul: ONDER Imam Hatip School Graduates and Members. https://www.researchgate.net/publication/332446236.

Ulum, M. M. (2012). Revitalisasi Pendidikan Islam: Upaya Menanggulangi Krisis Pendidikan di Indonesia di Era Globalisasi. Journal of Pesantren Education, 7(1), 49-58.

Za, T. (2016). Perubahan Ideologi ke-Islaman Turki, Jurnal Edukasi, 2(2), 130-146. DOI: 10.22373/je.v2i2.812.

Zahran, M. (2019). Formulasi Pendidikan Islam Kontra Terorisme. Journal of Research and Thought of Islamic Education, 2(1), 61-76. 